Research Article

Published January 16, 2017

\title{
Diminished CD103 ( $\alpha E \beta$ 7) Expression on Resident T Cells from the Female Genital Tract of HIV-Positive Women
}

\section{STANDFIRST}

The expression of CD103 on T cells in the human FGT likely requires $\mathrm{CD} 4^{+} \mathrm{T}$ cells.

\author{
AUTHORS \\ David C. Moylan ${ }^{1}$, Paul A. Goepfert ${ }^{1,2}$, Mirjam-Colette Kempf ${ }^{3}$, Michael S. Saagg ${ }^{1}$, Holly E. Rich- \\ ter $^{4}$, Jiri Mestecky ${ }^{2}$, Steffanie Sabbaj ${ }^{1}$
}

\section{AFFILIATED INSTITUTIONS}

${ }^{1}$ Departments of Medicine, University of Alabama at Birmingham, Birmingham, Alabama ${ }^{2}$ Department of Microbiology, University of Alabama at Birmingham, Birmingham, Alabama ${ }^{3}$ School of Nursing and Department of Health Behavior, University of Alabama at Birmingham, Birmingham, Alabama

${ }^{4}$ Obstetrics and Gynecology, University of Alabama at Birmingham, Birmingham, Alabama

\section{CORRESPONDING AUTHOR}

Steffanie Sabbaj

205-975-7612

sabbaj@uab.edu
DOI

10.20411/pai.v1i2.166

\section{ABSTRACT}

Background: Tissue resident memory $\mathrm{T}$ cells ( $\operatorname{TrM}$ ) provide an enhanced response against infection at mucosal surfaces, yet their function has not been extensively studied in humans, including the female genital tract (FGT).

Methods: Using polychromatic flow cytometry, we studied TrM cells, defined as CD62L-CCR7$\mathrm{CD} 103^{+} \mathrm{CD} 9^{+} \mathrm{CD}^{+}$and $\mathrm{CD} 8^{+} \mathrm{T}$ cells in mucosa-derived $\mathrm{T}$ cells from healthy and HIV-positive women. 
Results: We demonstrate that TrM are present in the FGT of healthy and HIV-positive women. The expression of the mucosal retention receptor, CD103, from HIV-positive women was reduced compared to healthy women and was lowest in women with CD 4 counts $<500$ cells $/ \mathrm{mm}^{3}$. Furthermore, CD103 expression on mucosa-derived CD8 ${ }^{+} \mathrm{T}$ cells correlated with antigen-specific IFN- $\gamma$ production by mucosal $\mathrm{CD} 4^{+} \mathrm{T}$ cells and was inversely correlated with T-bet from $\mathrm{CD} 8^{+} \mathrm{CD} 103^{+}$mucosa-derived T cells.

Conclusions: These data suggest that $\mathrm{CD}^{+}{ }^{+} \mathrm{T}$ cells, known to be impaired during HIV-1 infection and necessary for the expression of CD103 in murine models, may play a role in the expression of CD103 on resident $\mathrm{T}$ cells from the human FGT.

Keywords: Tissue Resident Memory T cells, female genital tract, HIV-1, CD103, mucosal immunity, CD8 ${ }^{+} \mathrm{T}$ cells, CD4 T cells

\section{INTRODUCTION}

There is a large gap in our understanding of the role cell-mediated immunity plays in controlling infections within mucosal tissues and how local T-cell memory is established after infection between animal models and humans. Furthermore, there is limited information available from studies of the female genital tract (FGT) as compared to the gastrointestinal tract and other mucosal tissues. Data obtained from other mucosal sites may not be applicable to the FGT because the FGT must balance the induction of a protective immune response with the ability to preserve the developing fetus.

The ability of memory $\mathrm{T}$ cells to migrate into mucosal tissues allows these cells to gain access to the site of active infection. The expression of $\alpha E \beta 7$ (mucosal retention receptor, CD103), and the downregulation of CCR7 and CD62L (lymph node homing receptors) are known mechanisms leading to the maintenance of cells in mucosal tissue such as the lung, gut, and genital tract [1-5]. It is well established that HIV-specific $\mathrm{CD}^{+} \mathrm{T}$ cells isolated from peripheral blood mononuclear cells (PBMC) express distinct memory phenotypes compared to other virus-specific T cells (reviewed in [6] ) but information on mucosa-derived cells is lacking. The peripheral blood and mucosal compartments have been shown to contain distinct memory T-cell subsets that exhibit characteristic homing, differentiation, activation, polyfunctional, and proliferation capabilities $[\underline{4}$, 7-10], strongly suggesting unique functional abilities depending on where these $\mathrm{T}$ cells are located. This is turn supports the view that the site of migration influences the phenotype and function of these cells [11-14]. In addition, different memory T-cell subsets have specific abilities to control viral infections. For example, central memory T cells (Тсм) are long-lived memory cells that control infection after reencountering the pathogen and expanding, differentiating and trafficking to the appropriate compartment. On the other hand, effector memory T cells (Tem), are shortlived, differentiated, and located at the site of infection, and are capable of controlling infections much more rapidly $[\underline{14}, \underline{15}]$. In fact, studies with rhesus macaques demonstrated that a vaccine using CMV as the vector elicited Tem and was capable of early control of SIV [16]; this was not seen with traditional $\mathrm{CD}^{+} \mathrm{T}$-cell vaccines that elicit predominantly $\mathrm{Tcm}$ responses [17]. Studies in mice $[\underline{11}, \underline{12}, \underline{18-25}]$ have revealed a relatively new type of memory $\mathrm{T}$ cell, the tissue resident memory T cell (TrM). Recently, TrM have been studied in multiple human mucosal tissues, except for the FGT, obtained from organ donors [26]. These cells are maintained in non-lymphoid tissue and are thought to be stationary. Conflicting data in animal models as to whether TrM cells 
can be retained in tissues such as the skin, vagina, and intestinal tract in the absence or presence of antigen, suggest that these differences may vary depending on location and type of infection. Most importantly, these cells are not present in the peripheral blood and can only be studied by direct examination of non-lymphoid tissue. TrM cells have been proposed, together with Tem, to be the only cells capable of providing immediate protective immunity in tissues. However, phenotypically defined (CD62L-CCR7-CD $103^{+} \mathrm{CD}^{2} 9^{+}$) resident memory T cells [27] have not been described in the human FGT.

In mice, there is ample information available concerning the mechanism and signals $\mathrm{T}$ cells undergo to become protective TrM in the different tissues in which they reside. In this process CD $4^{+}$ $\mathrm{T}$ cells have been implicated in the migration of effector $\mathrm{CD}^{+} \mathrm{T}$ cells into the FGT [28], but not the skin [21]. More recently, it has been shown that $\mathrm{CD}^{+} \mathrm{T}$ cells are needed to guide the formation of $\mathrm{CD} 103^{+}$lung resident memory $\mathrm{CD} 8^{+} \mathrm{T}$ cells [29]. In addition, the downregulation of the transcription factor, T-bet, has been shown to be necessary for the expression of CD103 [29, $\underline{30}$ ]. Clearly these types of studies are very difficult to perform in humans. However, by studying TrM in HIV-positive women-individuals with dysregulated CD4 ${ }^{+} \mathrm{T}$ cells-we can determine whether the data obtained in murine models translate to humans.

In this report, we extend our studies using menstrual blood $(\mathrm{MB})$ as a surrogate mucosal tissue [31] along with tissues from the FGT to demonstrate that TrM CD8 ${ }^{+} \mathrm{T}$ cells are present in the FGT of healthy as well as HIV-positive women. We were also able to demonstrate the diminished expression of the homing retention receptor CD103 on mucosa-derived T cells in these HIV-positive women. Our data suggest that, in humans, the expression of CD103 on mucosa-derived T cells is also dependent on local $\mathrm{CD} 4^{+} \mathrm{T}$ cell help.

\section{METHODS}

\section{Subjects}

Menstruating healthy women $(\mathrm{N}=13)$ and HIV-positive women $(\mathrm{N}=27$, Table 1$)$ were recruited from the University of Alabama at Birmingham's (UAB) 1917 Clinic, the Alabama Vaccine Research Clinic, and the Women's Interagency HIV Study (WIHS) cohort at UAB to donate menstrual blood and peripheral blood. The ages for the healthy women ranged between $20-43$ years, with the median age 36 years. With the exception of one Caucasian woman, all volunteers were African American. Women enrolled in these studies had no active STI. Menstrual cups were provided to volunteers prior to menstruation with instructions on how to use them. Contents of menstrual cups were decanted into $50 \mathrm{ml}$ tubes containing amphotericin $\mathrm{B}(0.5 \mathrm{mg} / \mathrm{ml})$, penicillin/streptomycin $(100 \mathrm{U} / \mathrm{ml})$, and gentamicin $(100 \mathrm{mg} / \mathrm{ml})$ plus acid-citrate-dextrose solution (ACD) as the anticoagulant ( $5 \mathrm{ml} /$ tube). The antimicrobial and anticoagulant volumes added to the $50 \mathrm{ml}$ tubes were determined assuming $25 \mathrm{ml}$ of menstrual blood/tube. Samples were kept at room temperature (RT) and brought to the laboratory within 6 hours of collection. In addition, vaginal $(\mathrm{N}=36)$ and endometrial $(\mathrm{N}=8)$ tissue samples, derived as anonymous remnant surgical material, were obtained from otherwise healthy women undergoing reconstructive pelvic surgery or a hysterectomy. Written informed consent was obtained from all women who participated in this study. The Institutional Review Board of the University of Alabama at Birmingham approved the study. 
Table 1. Clinical information and demographics of HIV-infected women

\begin{tabular}{|c|c|c|c|c|c|c|c|}
\hline Volunteer\# & Age & $\begin{array}{c}\text { Race/ } \\
\text { Ethnicity }\end{array}$ & $\mathrm{ART}^{\mathrm{a}}$ & $\begin{array}{c}\text { Plasma } \\
\text { VL }^{\mathbf{b}} \\
\text { (copies } / \mathrm{ml})\end{array}$ & $\begin{array}{c}\text { Absolute } \\
\text { CD4 } \\
\left(\text { cells } / \mathrm{mm}^{3}\right)\end{array}$ & $\begin{array}{l}\text { CD4 Nadir } \\
\left(\text { cells } / \mathrm{mm}^{3}\right)\end{array}$ & $\begin{array}{c}\text { ART } \\
\text { Length } \\
\text { years }\end{array}$ \\
\hline $1 C-301$ & 31 & $\mathrm{AA}$ & yes & $<20$ & 809 & 389 & 9 \\
\hline 1C-302 & 32 & AA & yes & $<20$ & 866 & 616 & 2 \\
\hline $1 C-303$ & 31 & AA & yes & $<20$ & 763 & 486 & 6 \\
\hline 1C-304 & 48 & $\mathrm{AA}$ & yes & $<20$ & 661 & 154 & 4 \\
\hline 1C-305 & 34 & AA & yes & $<20$ & 623 & 301 & 7 \\
\hline $1 C-306$ & 32 & $\mathrm{AA}$ & yes & $<20$ & 501 & 435 & 5 \\
\hline $1 C-307$ & 38 & $\mathrm{C}$ & yes & $<20$ & 645 & 262 & 3 \\
\hline $1 C-308$ & 37 & $\mathrm{AA}$ & yes & $<20$ & 1019 & 431 & 6 \\
\hline 1C-309 & 41 & $\mathrm{AA}$ & no & $<20$ & 1038 & 851 & - \\
\hline $1 C-310$ & 49 & $\mathrm{AA}$ & no & $<20$ & 992 & 729 & - \\
\hline $1 C-311$ & 46 & AA & yes & $<20$ & 923 & 356 & 7 \\
\hline $1 C-312$ & 39 & $\mathrm{AA}$ & yes & 122 & 313 & 220 & 5 \\
\hline $1 C-313$ & 38 & $\mathrm{AA}$ & yes & $<20$ & 849 & 460 & 5 \\
\hline $1 \mathrm{~A}-101$ & 35 & $\mathrm{AA}$ & yes & $<20$ & 426 & 23 & 6 \\
\hline $1 \mathrm{~A}-102$ & 35 & $\mathrm{AA}$ & yes & $<20$ & 286 & 49 & 18 \\
\hline $1 \mathrm{~A}-103$ & 40 & $\mathrm{AA}$ & yes & 92 & 443 & 39 & 4 \\
\hline $1 \mathrm{~A}-104$ & 35 & AA & yes & 35 & 1578 & 575 & 5 \\
\hline $1 \mathrm{~A}-105$ & 37 & AA & yes & 445 & 696 & 363 & $1^{\mathrm{c}}$ \\
\hline WIHS 1 & 30 & $\mathrm{AA}$ & yes & $<20$ & 616 & 616 & 1 \\
\hline WIHS 2 & 46 & AA & yes & $<20$ & 399 & 154 & 8 \\
\hline WIHS 3 & 39 & $\mathrm{AA}$ & no & $<20$ & 1048 & 974 & - \\
\hline WIHS 4 & 36 & AA & no & 9369 & 280 & 276 & - \\
\hline WIHS 5 & 45 & $\mathrm{AA}$ & yes & 10700 & 169 & 44 & 3 \\
\hline WIHS 6 & 37 & $\mathrm{AA}$ & yes & $<20$ & 349 & 220 & 3 \\
\hline WIHS 7 & 43 & AA & yes & 3720 & 803 & 416 & 5 \\
\hline WIHS 8 & 35 & AA & yes & $<20$ & 1096 & 460 & 3 \\
\hline WIHS 9 & 35 & $\mathrm{AA}$ & yes & $<20$ & 433 & 275 & 2 \\
\hline
\end{tabular}

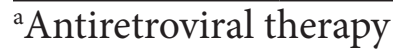

${ }^{b}$ Viral load

cmonth 


\section{Isolation of menstrual blood cells}

$\mathrm{MB}$ was obtained from women on day 1 and/or 2 of the menstrual cycle. Briefly, MB was diluted 1:2 in PBS, without $\mathrm{Ca}^{++} / \mathrm{Mg}^{++}$, layered onto Ficoll-Paque PLUS (GE Healthcare, Piscataway, NJ) and centrifuged at $800 \mathrm{xg}$ for $25 \mathrm{~min}$. at RT as previously described [31]. Interface containing buffy coat was removed; PBS was added and spun down at $400 \mathrm{x} g$ for $10 \mathrm{~min}$ twice. If the cell pellet contained RBC, it was spun down, the supernatant discarded, and the pellet resuspended. Then $5 \mathrm{~mL}$ cold ammonium-chloride-potassium buffer (ACK) was added to the pellet for $5 \mathrm{~min}$. Cell lysis was stopped by filling the tube with PBS and centrifuging at $400 \mathrm{x} g$ for $10 \mathrm{~min}$. Supernatant was discarded. If the pellet still appeared to have $\mathrm{RBC}$, this procedure was repeated up to 2 more times. Cell pellets were resuspended in media. If the sample contained too many particulates, cell suspension was passed through a $70 \mu \mathrm{M}$ nylon cell strainer (BD Falcon, Franklin Lakes, NJ) to remove residual tissue. PBMC were obtained by standard density centrifugation. Cells were counted and used for surface staining and/or intracellular cytokine assays.

\section{Isolation and purification of lymphocytes from tissue}

Tissue segments were obtained as either vaginal or endometrial surgical samples after pelvic reconstructive surgery. Lymphocytes were isolated by dissecting and mincing tissue with a scalpel into the smallest possible fragments. Fragments were transferred to $50 \mathrm{ml}$ conical tubes containing $30 \mathrm{ml}$ of warm $0.05 \%$ collagenase (Sigma type II collagenase \#C6885) in $7.5 \%$ FBS RPMI media and incubated for $15 \mathrm{~min}$ at $37^{\circ} \mathrm{C}$. Partially digested tissue was mechanically disrupted $2 \mathrm{x}$ using a $16 \mathrm{~g}$ blunt needle attached to a $20 \mathrm{ml}$ syringe. Tissue was incubated for an additional 15 min at $37^{\circ} \mathrm{C}$. Cell suspension was passed through a $40 \mu \mathrm{M}$ nylon cell strainer (BD Falcon, Franklin Lakes, NJ) and RPMI + 15\% FBS (R15) was added to quench enzyme activity. Cell suspension was pelleted $2 \mathrm{x}$ at $300 \mathrm{x}$ g for $10 \mathrm{~min}$ at RT. After the second wash, the cell pellet was resuspended in $5 \mathrm{ml}$ of $\mathrm{R} 15$, and placed at $37^{\circ} \mathrm{C}$ with a loose cap. Collagenase digestion was repeated $2 \mathrm{x}$. All 3 pellet fractions were combined and resuspended in $50 \mathrm{ml} \mathrm{R} 15$ and pelleted at $300 \mathrm{x} \mathrm{g}$ for $10 \mathrm{~min}$. Supernatant was discarded and the remaining cell suspension was resuspended in 1-3 ml of RPMI containing $10 \%$ AB serum. Cells were counted and used for the various assays.

\section{Surface marker staining}

Phenotypic characterization of menstrual blood cells (MBC), mononuclear cells isolated from tissue, and PBMC employed cell-surface markers CD3-Alexa780 (eBioscience, San Diego, CA), CD8-V500, CD45-PEcy7, CD62L-FITC, CD69-APC, CD103-PE ( $\alpha$ E $\beta 7)$, CD197-PercpCy5.5 (CCR7), CD4-Qdot655 (ThermoFisher, Waltham, MA), and fluorescent LIVE/DEAD Fixable Blue Dead Cell Stain (Molecular probes, Invitrogen, CA). Stained cells were acquired using a BD Calibur flow cytometer (Becton Dickinson [BD], San Jose, CA) and analyzed with FlowJo Version 9.9 software for Mac (TreeStar, San Carlos, CA). We ran at least 100,000 gated lymphocytes for each stained specimen. Fluorescence minus one (FMO) on cells stimulated with staphylococcus enterotoxin B (SEB) was used to set gates for the TrM cells (CD62L-, CCR7-, CD103+, CD69+). All antibodies were obtained from BD Biosciences, San Jose, California unless otherwise noted.

\section{Antigens}

Pools of overlapping HIV peptides (15-mers overlapping by 11, NIH AIDS repository) from the following proteins: Gag, Pol, Nef, and Env. PDBu/ionomycin (phorbol-12,13 dibutyrate) and/or SEB (Sigma-Aldrich, St. Louis, MO) were used as positive controls and unstimulated cells as a negative control. 


\section{Intracellular cytokine staining}

Intracellular cytokine staining was performed as previously described [ $\underline{31}, \underline{32}]$. MBC, PBMC, and mononuclear cells isolated from tissue were resuspended in RPMI containing 10\% human $\mathrm{AB}$ serum, and co-stimulatory monoclonal antibodies (anti-CD28 and anti-CD49d, each at $1 \mu \mathrm{g} /$ $\mathrm{ml}$ ) were added to each tube along with $50 \mathrm{U} / \mathrm{ml}$ of Benzonase (Novagen, Madison, WI). Cells were pulsed with the appropriate antigen followed by the addition of $10 \mu \mathrm{g} / \mathrm{ml}$ Monensin (Golgistop, BD Biosciences, San Jose, CA). Cells were then incubated at $37^{\circ} \mathrm{C}, 5 \% \mathrm{CO}_{2}$, for 6 hours, and placed at $4^{\circ} \mathrm{C}$ overnight. The following day cells were labeled with a fluorescent LIVE/DEAD fixable Blue Dead Cell Stain (Molecular probes, Invitrogen, CA). The surface phenotype of samples was determined by first staining with CCR7 and placing in a $37^{\circ} \mathrm{C}$ water bath for $20 \mathrm{~min}$ in the dark. This was followed by staining with the remaining surface antibodies for $20 \mathrm{~min}$ at RT in the dark. Cells were washed in PBS, followed by permeabilization with the Cytofix/cytoperm reagent (BD, San Jose, CA) for 20 min at RT in the dark. Intracellular cytokine staining followed using anti-IFN- $\gamma$-Alexa700 conjugated antibody. Using a second panel of antibodies, T-bet conjugated to Alexa Fluor488 was also measured. At least 100,000 lymphocytes were acquired from each sample using a BD LSR II flow cytometer (Becton Dickinson [10], San Jose, CA). Data were analyzed using FlowJo Version 9.9 software (TreeStar, San Carlos, CA). Lymphocytes were analyzed based on forward and side scatter profiles for PBMC and by gating on CD45 for MB and tissues followed by the exclusion of dead cells. Cytokines produced were measured using the $\mathrm{CD} 3^{+} \mathrm{CD} 4^{+}$gates relative to the media control values and these gates were applied to all samples with different antigens from the same individual. Surface staining was determined using FMOs as above. All antibodies were obtained from BD Biosciences, San Jose, California unless otherwise noted. We used Fisher's exact test to compare the number of cytokine-producing cells between the antigen-stimulated and unstimulated (media alone) samples to determine whether a response is considered positive. A $P$ $<0.05$ was used for $\mathrm{CD}^{+}$responses from $\mathrm{MBC}$. To be considered a positive response the frequency also had to be $>0.05 \%$.

\section{Statistics}

Statistical analyses were performed using the non-parametric Wilcoxon Signed Rank test for paired samples; otherwise the Mann-Whitney U test was used. Analyses were done with Graphpad Prism software 5.0 for Mac. Differences were considered to be significant on the basis of $95 \%$ confidence intervals $(P<0.05)$. 


\section{A. CD8}

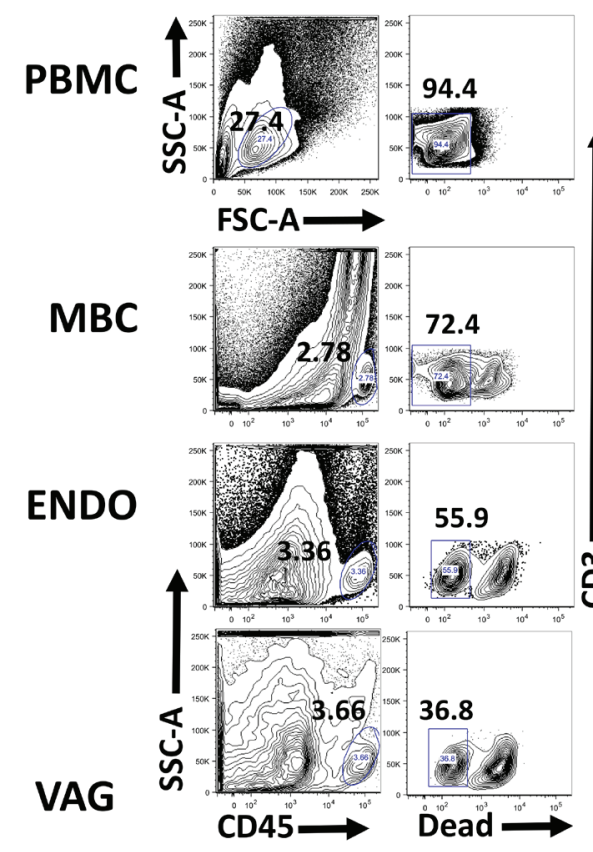

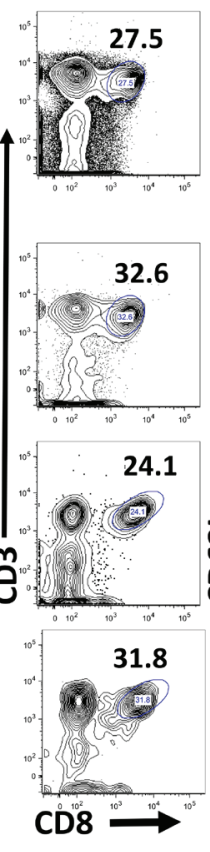
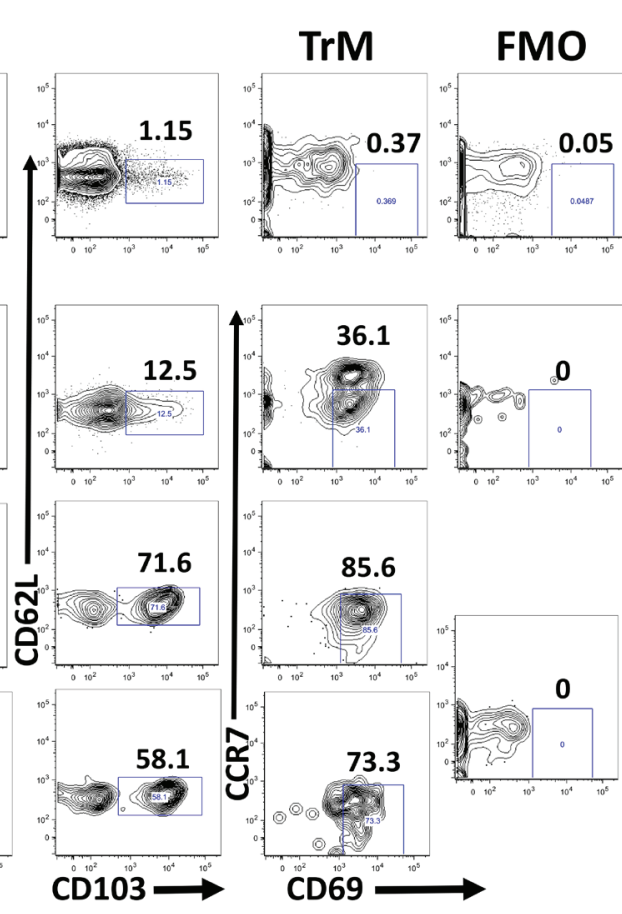

B. CD4
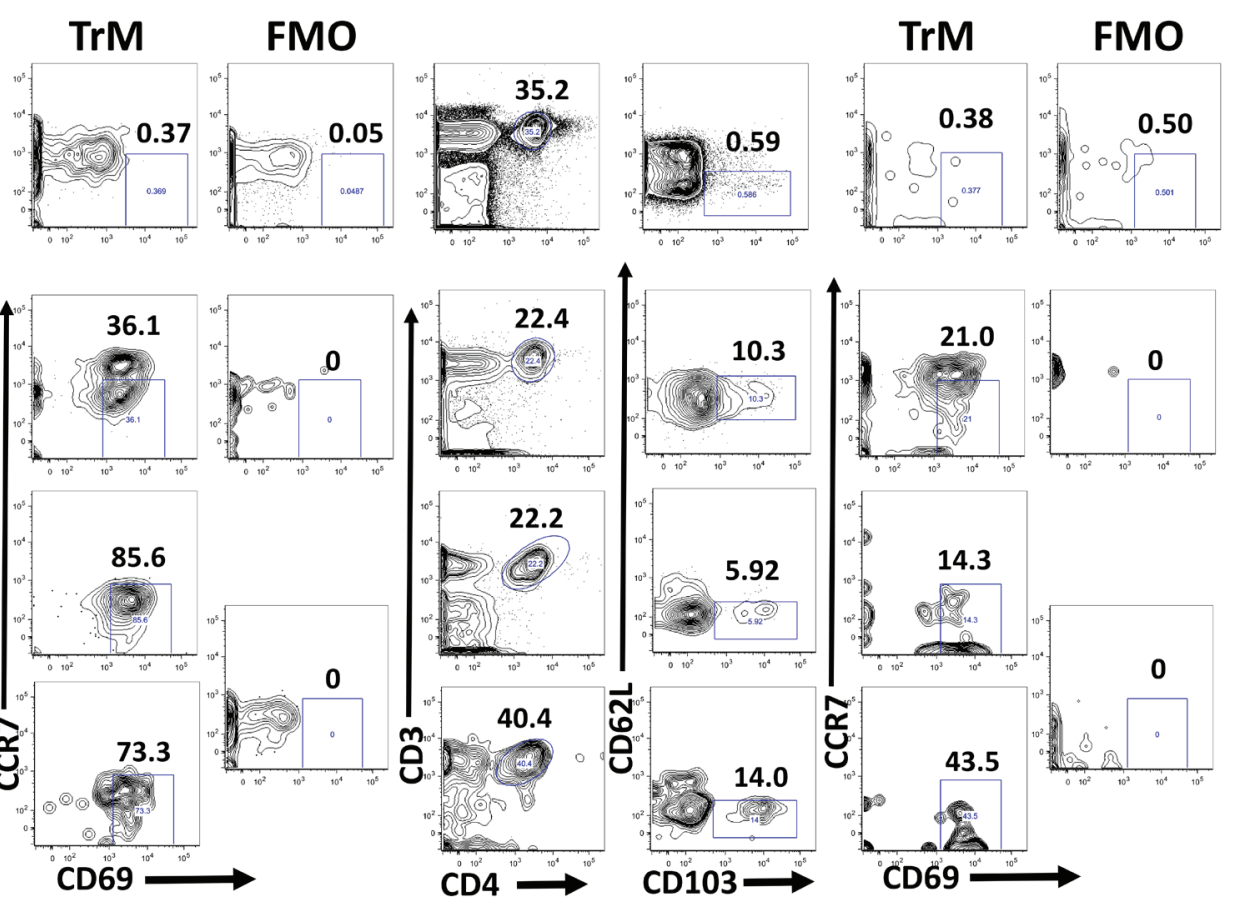

Figure 1. Sample gating strategy. (A) The percent $\mathrm{CD} 3{ }^{+} \mathrm{CD}^{+}$and (B) $\mathrm{CD}^{+}{ }^{+} \mathrm{CD} 4^{+}$Tissue Resident $\mathrm{T}$ cells $\left(\mathrm{CD} 62 \mathrm{~L}-\mathrm{CD} 103^{+} \mathrm{CCR} 7-\mathrm{CD} 69^{+}\right)$is shown . The flow plots represent TrM cells present in paired PBMC and MBC from an HIV-positive woman and endometrial (ENDO) and vaginal tissue from an anonymous remnant sample. Fluorescence minus one (FMO) is set individually for PBMC, MBC, and ENDO/VAG (which share the same FMO, because they are from the same donor). The percent of the gated population is shown above the gate. 


\section{RESULTS}

\section{Tissue Resident Memory T cells (TrM) in the female genital tract}

Several studies have suggested the presence of TrM in the FGT of humans [33, 34]. To determine whether tissue-resident memory T cells defined as CD62L-CCR7-CD $103^{+} \mathrm{CD} 69^{+}$are established in the FGT of humans, we used cells obtained from MB and paired PBMC from HIV-positive and healthy women. In addition, vaginal (VAG) and endometrial (ENDO) samples from anonymous remnant tissue were used as a source of T cells. The gating strategy we used to detect CD8 ${ }^{+}$(Figure 1A) and $\mathrm{CD}^{+}$(Figure 1B) TrM cells is depicted. Fluorescence minus one (FMO) was used to determine where to place the CD69 gate. In Figure 2A we compare the presence of TrM in PBMC and $\mathrm{MBC}$ from HIV-negative women and from VAG and ENDO tissue from anonymous remnant samples. By gating on live $\mathrm{CD}^{+} \mathrm{CD} 8{ }^{+} \mathrm{CD} 62 \mathrm{~L}-\mathrm{CD} 103^{+} \mathrm{CCR} 7-\mathrm{CD} 69^{+} \mathrm{T}$ cells, we demonstrated that $\mathrm{TrM} \mathrm{CD} 8^{+} \mathrm{T}$ cells are present in menstrual blood cells (MBC, median 1.7\%), vaginal (VAG, median 29\%) and endometrial (ENDO, median 6\%) tissue but diminished in PBMC (median $0.07 \%$ ) (Figures 1 and $2 \mathrm{~A}$ ).

A. HIV- $(C D 8+)$
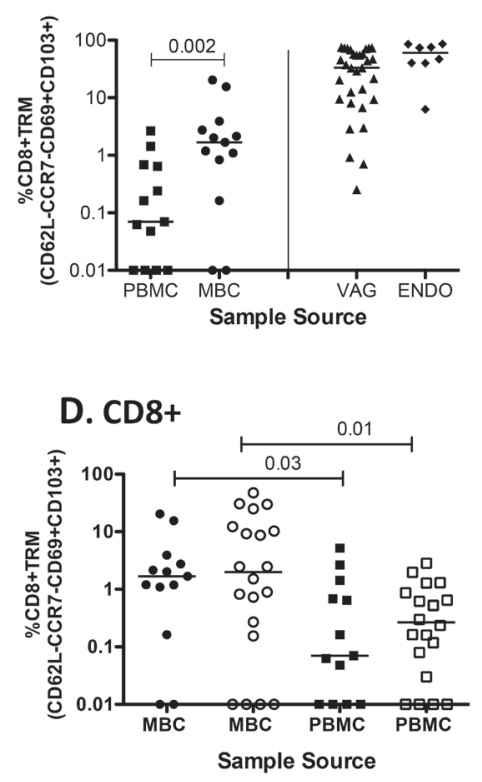

B. HIV- (CD8+)

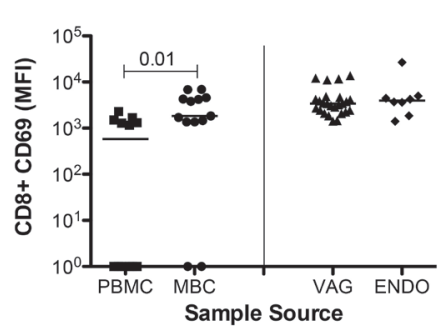

E. CD8+

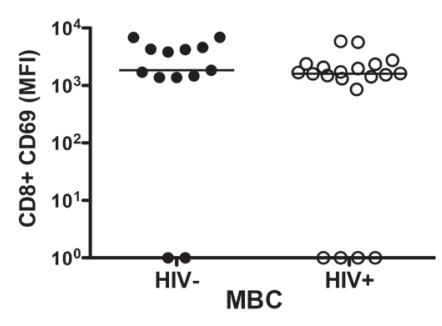

C. HIV- (CD4+)

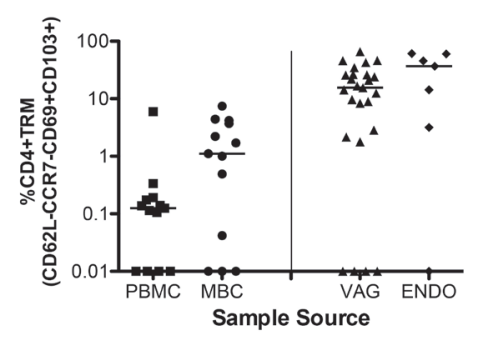

F. HIV+ (CD4+)

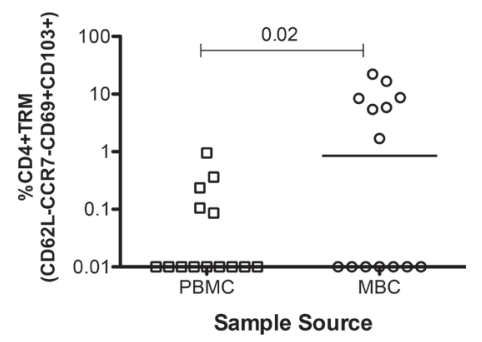

Figure 2. Tissue Resident $\mathrm{T}$ cells are present in the FGT. (A) The percentage of $\mathrm{CD} 3^{+} \mathrm{CD} 8^{+} \mathrm{TrM}(\mathrm{CD} 62 \mathrm{~L}-$ $\left.\mathrm{CD}_{103}{ }^{+} \mathrm{CCR} 7-\mathrm{CD} 69^{+}\right)$cells present in paired $\mathrm{PBMC}$ and $\mathrm{MBC}$ from HIV-negative women and from vaginal (VAG) and endometrial (ENDO) tissue from anonymous remnant samples. (B) Mean Fluorescence Intensity (MFI) of $\mathrm{CD}^{+} \mathrm{CD} 69^{+} \mathrm{T}$ cells for paired $\mathrm{PBMC}$ and $\mathrm{MBC}$ from $\mathrm{HIV}$ negative women and from VAG and ENDO tissue from anonymous remnant samples. (C) The percentage of $\mathrm{CD} 3^{+} \mathrm{CD} 4{ }^{+} \mathrm{TrM}$ cells present in paired PBMC and MBC from HIV-negative women and VAG and ENDO tissue from anonymous remnant samples. (D) The percent of $\mathrm{CD}^{+} \mathrm{CD}^{+}$TrM present in paired $\mathrm{MBC}$ and PBMC between HIV-negative and positive women. (E) CD69 MFI between $\mathrm{CD} 8^{+} \mathrm{CD} 69^{+} \mathrm{TrM}$ from MB cells from HIV negative and positive women. (F) The percentage of $\mathrm{CD}^{+} \mathrm{CD}^{+} \mathrm{TrM}$ cells present in paired PBMC and MBC from HIV positive women. Fluorescence minus one (FMO) is set individually for PBMC and MBC. Horizontal line represents median value. Statistically significant differences $(P<0.05)$ were obtained using the Wilcoxon Rank test for paired samples and for unpaired we used the Mann Whitney test. Although not noted in the graph, differences were also detected between PBMC and MBC and tissues (VAG and ENDO). 
Moreover, when we compare the frequency of TrM between MBC from HIV-negative (closed circles) and HIV-positive (open circles) samples we detect no differences (Figure 2D). TrM are also enriched in $\mathrm{MBC}$ from HIV-positive samples (median 2.5\%) when compared to paired PBMC (median 0.25\%) (Figure 2D). When we compared the MFI of $\mathrm{CD}^{+} \mathrm{CD}^{2} 9^{+} \mathrm{T}$ cells from $\mathrm{PBMC}$ and $\mathrm{MBC}$ from the HIV-negative women, we also detected significant differences between PBMC and $\mathrm{MBC}$ (Figure 2B) in the expression of CD69. However, the MFI of $\mathrm{CD}^{+} \mathrm{CD} 69^{+}$on $\mathrm{T}$ cells isolated from MB was not different between HIV-negative and HIV-positive samples (Figure 2E). We then analyzed whether $\mathrm{CD}^{+}{ }^{+} \mathrm{CD} 4^{+} \mathrm{TrM}$ were present in the FGT of HIV-negative women by using MBC (median 1.1\%) and tissue (VAG, median 15.5\%, and ENDO, median 36.8\%) (Figure 2C). Our data demonstrate that $\mathrm{CD} 4^{+}$TrM are also present in the FGT when compared to PBMC (median $0.11 \%$ ). When we analyzed $\mathrm{CD} 4^{+} \mathrm{TrM}$ in HIV-seropositive women, these were also detected (Figure $2 \mathrm{~F}$ ). Just as with $\mathrm{CD} 3^{+} \mathrm{CD}^{+} \mathrm{TrM}$, we observed no differences in the percentage of $\operatorname{TrM}$ or the expression of CD69 (MFI) between HIV-positive and negative women when we analyze $\mathrm{CD}^{+} \mathrm{CD}^{+} \mathrm{T}$ cells isolated from $\mathrm{MB}$ (data not shown).

\section{Reduced CD103 expression on T cells derived from the female genital tract of HIV-positive women}

Recent studies in mice observed that homing of TrM cells is impaired when CD4 $4^{+} \mathrm{T}$ cell help is lacking due to the inability to express the mucosal retention receptor CD103 [29]. This impairment in CD103 expression is dependent on the production of IFN- $\gamma$ by CD4 ${ }^{+}$T cells and could be rescued with the reduction of T-bet expression on $\mathrm{CD}^{+} \mathrm{TrM}$. Consequently, we wanted to determine whether CD4 help plays a similar role in humans and analyzed the expression of CD103 on MBC from HIV-positive women (our impaired CD4 T cell help group) versus healthy women. We demonstrated that the expression of $\mathrm{CD} 103$ was reduced on $\mathrm{CD} 103^{+} \mathrm{CD} 3^{+} \mathrm{CD} 8^{+}$ and $\mathrm{CD}_{103}{ }^{+} \mathrm{CD}^{+} \mathrm{CD}^{+}$(Figures $3 \mathrm{~A}$ and $3 \mathrm{~B}$ ) $\mathrm{T}$ cells isolated from HIV-positive menstrual blood $(\mathrm{HIV}+\mathrm{MB})$ compared to negative samples (HIV-MB). We further demonstrate that if we stratify the HIV-positive women by their absolute CD4 count, differences in the expression of CD103 are observed between $\mathrm{CD}_{103}{ }^{+} \mathrm{CD}^{+} \mathrm{T}$ cells isolated from $\mathrm{MB}$ from the HIV-negative women (closed black circles) when compared to $\mathrm{CD} 103^{+} \mathrm{CD}^{+} \mathrm{T}$ cells from HIV-positive women with absolute CD 4 counts less than 500 cells $/ \mathrm{mm}^{3}$ (gray circles) (Figure 3C). These data also indicate that the differences in the expression of CD103 on T cells between HIV-infected and uninfected women is most likely driven by the samples from the HIV-positive women with CD $4<500 \mathrm{cells} / \mathrm{mm}^{3}$. If we stratify the samples based on whether the women were viremic (VL > 20) or aviremic, there is a trend $(P=0.09)$ for higher CD103 expression in the aviremic group (data not shown). Although the clinical absolute or percent of CD4 did not correlate with the expression of CD103 (data not shown), the expression of $\mathrm{CD} 103$ on $\mathrm{CD} 103^{+} \mathrm{CD}^{+} \mathrm{T}$ cells isolated from the MB of HIV-positive women correlated with HIV-specific IFN- $\gamma$ production from $\mathrm{CD}^{+}{ }^{+} \mathrm{T}$ cells isolated from the $\mathrm{MB}$ from these women (Figure 3D). Lastly, the expression of CD103 was inversely correlated with T-bet on $\mathrm{CD}^{+} \mathrm{T}$ cells isolated from $\mathrm{MB}$ (Figure $3 \mathrm{E}$ ), suggesting that T-bet downregulation is necessary for the expression of CD103, as shown in murine studies [리]. A sample gating strategy for T-bet is shown in Figure 3F. It is worth noting that most of the HIV-positive women were on cART and many had CD4 T-cell numbers within the normal range (Table 1). 
A.
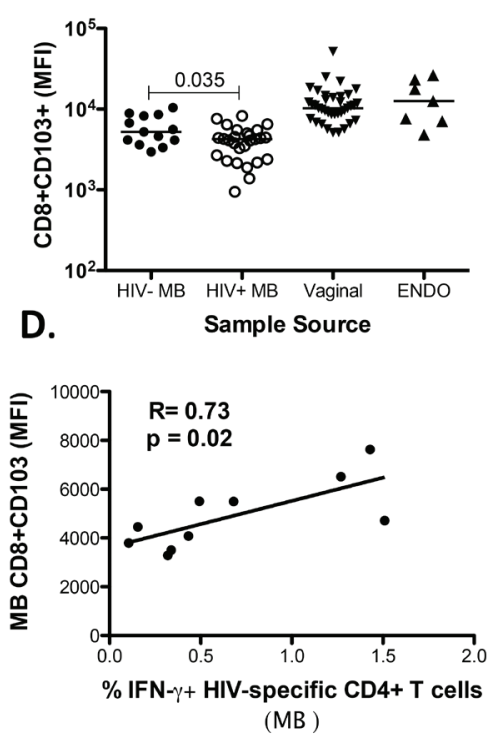

B.

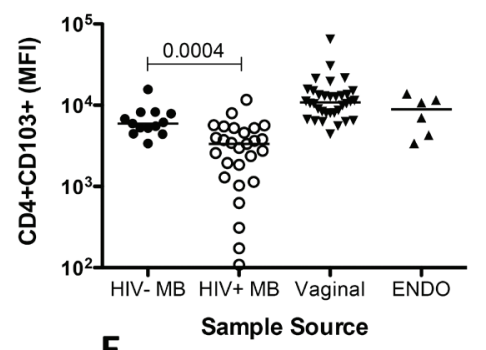

E.

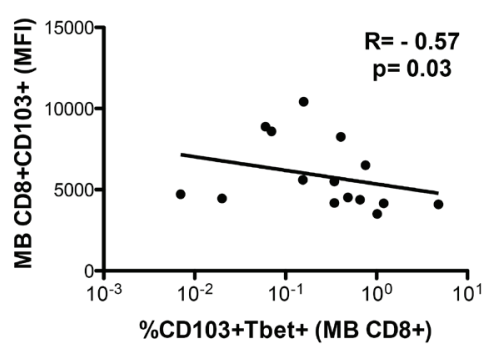

C.

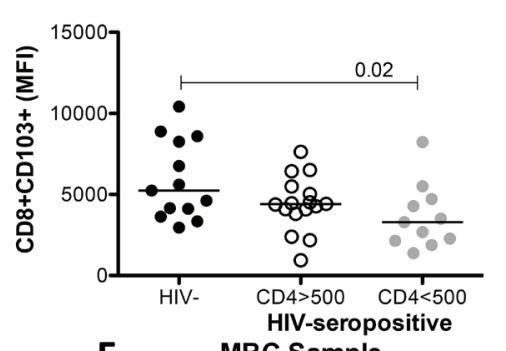

F.

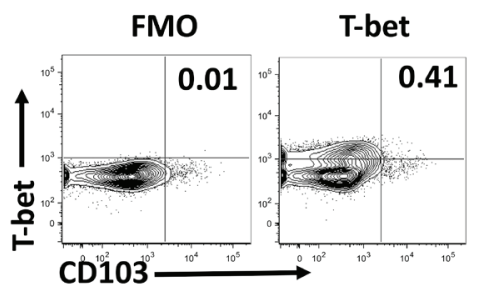

Figure 3. Reduction in the expression of CD103 in MB from HIV-positive women. (A) The mean fluorescence intensity (MFI) of CD103 expression on $\mathrm{CD}^{+}{ }^{+} \mathrm{CD} 8^{+} \mathrm{T}$ cells. (B) The MFI of CD103 expression on $\mathrm{CD}^{+}{ }^{+} \mathrm{CD} 4{ }^{+} \mathrm{T}$ cells. $\mathrm{T}$ cells were isolated from $\mathrm{MB}$ from HIV-positive and negative women and vaginal and endometrial samples from anonymous samples. (C) The MFI of CD103 expression on $\mathrm{CD}^{+} \mathrm{CD} 8^{+} \mathrm{T}$ cells isolated from MB from HIV-negative and HIV-positive women stratified by absolute CD4 T cell number $\left(\right.$ cells $/ \mathrm{mm}^{3}$ ) (D) Correlation between $\mathrm{CD} 103$ expression (MFI) on $\mathrm{CD} 103^{+} \mathrm{CD}^{+}{ }^{+} \mathrm{CD} 8{ }^{+} \mathrm{T}$ cells isolated from menstrual blood of HIV-positive women and the production of IFN- $\gamma$ from $\mathrm{CD}^{+}{ }^{+} \mathrm{CD} 3^{+} \mathrm{T}$ cells isolated from menstrual blood of HIV-positive women specific for HIV. The IFN- $\gamma$ production from $\mathrm{CD} 4{ }^{+} \mathrm{T}$ cells from all HIV antigens demonstrating a positive response was added for each individual. (E) Correlation between $\mathrm{CD} 103$ expression (MFI) on $\mathrm{CD}_{103}{ }^{+} \mathrm{CD}^{+} \mathrm{CD}^{+} \mathrm{T}$ cells isolated from menstrual blood and the percent of T-bet ${ }^{+} \mathrm{CD}^{+} \mathrm{CD}^{+} \mathrm{CD} 103^{+} \mathrm{T}$ cells isolated from menstrual blood. (F) Sample gating strategy for T-bet from $\mathrm{CD}^{+} \mathrm{T}$ cells isolated from $\mathrm{MB}$ from an HIV-infected sample. Horizontal line represents median value. Statistically significant differences $(P<0.05)$ were obtained using the Wilcoxon Rank test for paired samples and the Mann Whitney test for unpaired samples. Although not noted in the graph, differences were also detected between MBC and tissues (VAG and ENDO). Correlations were determined using the Spearman correlation.

\section{DISCUSSION}

It has been shown repeatedly that TrM play an essential role in the containment of non-lymphoid infections of the skin, lung, and gastrointestinal and genital tracts in murine models $[\underline{19}, \underline{21}, \underline{24}$, $\underline{29}, \underline{35-38]}$. In humans only a few studies have been conducted, primarily using skin TrM [34, $\underline{39}$, 40]. Recently, studies examining CD8 ${ }^{+} \mathrm{T}$ cells in the FGT $[\underline{33}, \underline{34}]$, were carried out whereby it was demonstrated that HSV-2-specific T cells were present in the FGT. However, phenotypic characterization of TrM using LN homing receptors (CCR7 and CD62L) and the mucosal retention receptor CD103 along with CD69 expression were not performed, in order for parallels to murine studies to be made. Analyses of human FGT are challenging due to the need for large tissue samples to obtain sufficient numbers of cells. Therefore, remnant tissues are used instead of small biopsies. Although remnant tissues are useful for many immunologic evaluations, anti- 
gen-specific studies are precluded and therefore associations with viral control, for example, are not possible. In addition, the inability to perform challenge experiments, to use knockouts, or to treat with depleting antibodies limits the kinds of studies possible in humans. Despite these drawbacks, in this report we demonstrated that, phenotypically, CD62L-CCR7-CD $103^{+} \mathrm{CD} 69^{+}$ TrM CD8 ${ }^{+} \mathrm{T}$ cells are present in the FGT of both healthy and HIV-positive women. We also established the presence of $\mathrm{CD}^{+} \mathrm{CD}^{+}$TrM cells (Figures $2 \mathrm{C}$ and $2 \mathrm{~F}$ ) as has been described previously in animal models [ $\underline{36}, \underline{41-43}]$ and recently in humans [44]. Lastly, we demonstrated that the expression of the retention receptor CD103 is diminished in HIV-positive women.

Our data support the results of others [28] whereby $\mathrm{CD}^{+} \mathrm{T}$ cells were required for the migration of effector $\mathrm{CD}^{+} \mathrm{T}$ cells into the FGT. We demonstrated that the expression of CD103 is reduced on $\mathrm{MB}$ T cells isolated from HIV-positive women (Figures $3 \mathrm{~A}$ and $3 \mathrm{~B}$ ) and that this reduction is most pronounced on CD8 $\mathrm{T}$ cells from $\mathrm{HIV}$-infected women with reduced CD4 T cell numbers (Figure 3C). These results parallel data from Laidlaw et al. (2014), which demonstrate that functional $\mathrm{CD}^{+} \mathrm{T}$ cells are needed in the formation of lung $\mathrm{CD} 103^{+} \mathrm{CD} 8^{+} \mathrm{T}$ cells. Together our data suggest that, in humans too, functional $\mathrm{CD} 4^{+} \mathrm{T}$ cells are necessary for the formation of $\mathrm{CD} 8^{+}$ tissue resident $\mathrm{T}$ cells.

However, despite all of these associations, we were unable to correlate either absolute CD4 or percent of CD4 values obtained from clinical laboratory results with the presence of TrM in HIV-positive women. Our data suggest that despite the normal range of CD4 T cells, HIV-positive women most likely have impaired $\mathrm{CD}^{+} \mathrm{T}$ cells $[\underline{45}, \underline{46}]$ that are incapable of helping in the establishment of resident $\mathrm{CD}^{+} \mathrm{CD} 103^{+} \mathrm{T}$ cells in the FGT. To this end we demonstrated that the expression of CD103 on CD8 ${ }^{+} \mathrm{T}$ cells isolated from $\mathrm{MB}$ correlates with HIV-specific $\mathrm{CD} 4^{+} \mathrm{T}$ cells present in $\mathrm{MB}$ (Figure 3D) and is inversely correlated with the transcription factor T-bet, known to be downregulated during CD103 expression in mice (Figure 3E).

When we analyzed the data using percent of CD103 instead of the MFI of CD103 expression on $\mathrm{T}$ cells we noted that differences between PBMC and MBC remain (Supplemental Figures 1A, 1B, and 1D), but differences between HIV-infected and uninfected samples were not seen (data not shown). These data suggest that the decrease in the expression of CD103 is due to a reduction in the expression of CD103 and not to lower CD103 ${ }^{+} \mathrm{T}$ cell numbers. TGF- $\beta$ has been shown to be necessary for the expression of CD103 in murine models $[\underline{47}, \underline{48}]$ Therefore we measured the concentration of TGF- $\beta 1$ in plasma obtained from menstrual blood, and noted that it is significantly elevated compared to plasma obtained from peripheral blood (Supplemental Figures $1 \mathrm{E}$ and $1 \mathrm{~F}$ ), in line with a previous study showing the presence of TGF- $\beta 1$ using cervicovaginal lavage samples [49] and supporting data demonstrating that it is produced in the human endometrium [ $\underline{50}$ ]. However, differences between HIV-infected and healthy plasma samples were not detected (data not shown).

New evidence in murine studies suggests that TrM should be defined as resident cells in tissue that do not recirculate, because there appears to be substantial phenotypic heterogeneity in terms of surface expression of CD103 and CD69 on these cells [ $\underline{51}, \underline{52}]$. This observation should be taken into account when analyzing cells from human tissue, as single positive cells may also include resident memory cells (eg, CD103 ${ }^{+} \mathrm{CD} 69-$ or $\mathrm{CD} 103-\mathrm{CD}_{6} 9^{+}$). This discrepancy may partially explain why no differences are observed between HIV-positive and negative samples when $\mathrm{CD}_{103}{ }^{+} \mathrm{CD} 69^{+}$cells are analyzed. 
Although it is clear that MBC are not an exact representation of tissue-derived cells from the FGT and that $\operatorname{TrM}$ are lower in frequency in MB than in tissue, MB is still a useful substitute when studying cell-mediated immunity in the FGT. Our data using MB corroborate data from others in which a reduction in $\mathrm{CD}_{103^{+}} \mathrm{T}$ cells was observed between HIV-positive and HIV-negative individuals in other mucosal compartments such as the gastrointestinal tract [53] and breast milk [54], suggesting this dysfunction extends to various mucosal compartments.

Because most women in this report were receiving cART we were unable to determine whether TrM in the FGT play a role in HIV control. Despite this fact, the results generated demonstrate that $\operatorname{TrM}$ T cells are present in the FGT of women and that HIV infection impairs their function and/or localization. Moreover, we were unable to discern the role antigen plays in the generation or maintenance of TrM in the FGT. Further experiments aimed at determining antigen role in the maintenance and development of TrM need to be carried out.

Given that at the time of menstruation all hormones involved in the menstrual cycle are at their lowest levels, MB-derived cells should not be influenced by hormonal levels and comparisons between women should also not be influenced by differences in hormonal concentrations. Therefore, $\mathrm{MB}$ can now be added as one of the various sources of mucosal sampling available to study cell-mediated immunity in the FGT.

Understanding resident memory T-cell function in human tissues may enable our understanding of the type of cells needed to be generated in preventative vaccines for protection from pathogens infecting the mucosal surfaces of the FGT. Finally, this information adds to the body of knowledge of the human mucosal immune system.

\section{ACKNOWLEDGMENTS}

This work was supported by NIH grants AI116320, AI027767 (SS), and AI103401-01 (MCK and MSS). All flow cytometry experiments were performed by the UAB CFAR Flow Cytometry Core/ Joint UAB Flow Cytometry Facility and were funded in part by NIH/NIAID P30 AI27767. We thank Catrena Johnson, Pamela Cunningham, and Zenoria Causey for recruiting the women in this study; Alice Howell and Kathy Carter for procuring remnant tissue samples; and all of the volunteers for participating in these studies.

Data in this manuscript were collected by the Women's Interagency HIV Study (WIHS). The contents of this publication are solely the responsibility of the authors and do not represent the official views of the National Institutes of Health (NIH). WIHS Principal Investigators: UAB-MS WIHS (Michael Saag, Mirjam-Colette Kempf, and Deborah Konkle-Parker); U01-AI-103401. The WIHS is funded primarily by the National Institute of Allergy and Infectious Diseases (NIAID), with additional co-funding from the Eunice Kennedy Shriver National Institute of Child Health and Human Development (NICHD), the National Cancer Institute (NCI), the National Institute on Drug Abuse (NIDA), and the National Institute on Mental Health (NIMH). Targeted supplemental funding for specific projects is also provided by the National Institute of Dental and Craniofacial Research (NIDCR), the National Institute on Alcohol Abuse and Alcoholism (NIAAA), the National Institute on Deafness and other Communication Disorders (NIDCD), and the NIH Office of Research on Women's Health. WIHS data collection is also supported by UL1-TR000004 (UCSF CTSA) and UL1-TR000454 (Atlanta CTSA). 


\section{AUTHOR CONTRIBUTIONS}

Conceptualization: SS and JM; Formal analysis: SS; Investigation: DCM and SS; Resources: HER, MCK, PAG, and MSS; Writing original draft: SS; Writing, reviewing and editing: SS, HER, JM, PAG, MCK, and MSS; Supervision: SS; Visualization: S; Funding acquisition: SS, MCK, and MSS.

\section{POTENTIAL CONFLICTS OF INTEREST}

The authors have no competing financial interests.

\section{REFERENCES}

1. Kantele A, Zivny J, Hakkinen M, Elson CO, Mestecky J. Differential homing commitments of antigen-specific $\mathrm{T}$ cells after oral or parenteral immunization in humans. J Immunol. 1999;162(9):5173-7. PubMed PMID: 10227989.

2. Masopust D, Jiang J, Shen H, Lefrancois L. Direct analysis of the dynamics of the intestinal mucosa CD8 T cell response to systemic virus infection. J Immunol. 2001;166(4):2348-56. PubMed PMID: 11160292.

3. Masopust D, Vezys V, Marzo AL, Lefrancois L. Preferential localization of effector memory cells in nonlymphoid tissue. Science. 2001;291(5512):2413-7. PubMed PMID: 11264538. doi: $10.1126 /$ science. 1058867

4. Sallusto F, Lenig D, Forster R, Lipp M, Lanzavecchia A. Two subsets of memory T lymphocytes with distinct homing potentials and effector functions. Nature. 1999;401(6754):708-12. PubMed PMID: 10537110. doi: 10.1038/44385

5. Tang VA, Rosenthal KL. Intravaginal infection with herpes simplex virus type-2 (HSV2) generates a functional effector memory $\mathrm{T}$ cell population that persists in the murine genital tract. J Reprod Immunol. 2010;87(1-2):39-44. PubMed PMID: 20688399. doi: 10.1016/j.jri.2010.06.155

6. Appay V, Rowland-Jones SL. Lessons from the study of T-cell differentiation in persistent human virus infection. Semin Immunol. 2004;16(3):205-12. PubMed PMID: 15130505. doi: 10.1016/j.smim.2004.02.007

7. Appay V, van Lier RA, Sallusto F, Roederer M. Phenotype and function of human T lymphocyte subsets: consensus and issues. Cytometry A. 2008;73(11):975-83. PubMed PMID: 18785267. doi: 10.1002/cyto.a.20643

8. Hamann D, Baars PA, Rep MH, Hooibrink B, Kerkhof-Garde SR, Klein MR, van Lier RA. Phenotypic and functional separation of memory and effector human CD8+ T cells. J Exp Med. 1997;186(9):1407-18. PubMed PMID: 9348298. Pubmed Central PMCID: 2199103.

9. Lanzavecchia A, Sallusto F. Understanding the generation and function of memory T cell subsets. Curr Opin Immunol. 2005;17(3):326-32. PubMed PMID: 15886125. doi: 10.1016/j.coi.2005.04.010

10. Riou C, Treurnicht F, Abrahams MR, Mlisana K, Liu MK, Goonetilleke N, Koup R, Roederer M, Abdool Karim S, de Bruyn G, Williamson C, Gray CM, Burgers WA. Increased Memory Differentiation Is Associated with Decreased Polyfunc- 
tionality for HIV but Not for Cytomegalovirus-Specific CD8+ T Cells. J Immunol. 2012;189(8):3838-47. PubMed PMID: 22966086. Pubmed Central PMCID: 3466366. doi: 10.4049/jimmunol.1201488

11. Klonowski KD, Williams KJ, Marzo AL, Blair DA, Lingenheld EG, Lefrancois L. Dynamics of blood-borne CD8 memory T cell migration in vivo. Immunity. 2004;20(5):551-62. PubMed PMID: 15142524.

12. Lee YT, Suarez-Ramirez JE, Wu T, Redman JM, Bouchard K, Hadley GA, Cauley LS. Environmental and antigen receptor-derived signals support sustained surveillance of the lungs by pathogen-specific cytotoxic T lymphocytes. J Virol. 2011;85(9):408594. PubMed PMID: 21345961. Pubmed Central PMCID: 3126261. doi: 10.1128/ JVI.02493-10

13. Marzo AL, Yagita H, Lefrancois L. Cutting edge: migration to nonlymphoid tissues results in functional conversion of central to effector memory CD8 T cells. J Immunol. 2007;179(1):36-40. PubMed PMID: 17579018. Pubmed Central PMCID: 2861291.

14. Zammit DJ, Turner DL, Klonowski KD, Lefrancois L, Cauley LS. Residual antigen presentation after influenza virus infection affects CD8 $\mathrm{T}$ cell activation and migration. Immunity. 2006;24(4):439-49. PubMed PMID: 16618602. Pubmed Central PMCID: 2861289. doi: 10.1016/j.immuni.2006.01.015

15. Tan WG, Jin HT, West EE, Penaloza-Macmaster P, Wieland A, Zilliox MJ, McElrath MJ, Barouch DH, Ahmed R. Comparative analysis of SIV Gag specific effector and memory CD8 T cells induced by different adenovirus vectors. J Virol. 2012. PubMed PMID: 23175355. doi: 10.1128/JVI.02055-12

16. Hansen SG, Ford JC, Lewis MS, Ventura AB, Hughes CM, Coyne-Johnson L, Whizin N, Oswald K, Shoemaker R, Swanson T, Legasse AW, Chiuchiolo MJ, Parks CL, Axthelm MK, Nelson JA, Jarvis MA, Piatak M, Jr., Lifson JD, Picker LJ. Profound early control of highly pathogenic SIV by an effector memory T-cell vaccine. Nature. 2011;473(7348):523-7. PubMed PMID: 21562493. Pubmed Central PMCID: 3102768. doi: $10.1038 /$ nature 10003

17. Horton H, Vogel TU, Carter DK, Vielhuber K, Fuller DH, Shipley T, Fuller JT, Kunstman KJ, Sutter G, Montefiori DC, Erfle V, Desrosiers RC, Wilson N, Picker LJ, Wolinsky SM, Wang C, Allison DB, Watkins DI. Immunization of rhesus macaques with a DNA prime/modified vaccinia virus Ankara boost regimen induces broad simian immunodeficiency virus (SIV)-specific T-cell responses and reduces initial viral replication but does not prevent disease progression following challenge with pathogenic SIVmac239. J Virol. 2002;76(14):7187-202. PubMed PMID: 12072518. Pubmed Central PMCID: 136301.

18. Casey KA, Fraser KA, Schenkel JM, Moran A, Abt MC, Beura LK, Lucas PJ, Artis D, Wherry EJ, Hogquist K, Vezys V, Masopust D. Antigen-independent differentiation and maintenance of effector-like resident memory $\mathrm{T}$ cells in tissues. J Immunol. 2012;188(10):4866-75. PubMed PMID: 22504644. Pubmed Central PMCID: 3345065. doi: $10.4049 /$ jimmunol.1200402 
19. Gebhardt T, Wakim LM, Eidsmo L, Reading PC, Heath WR, Carbone FR. Memory T cells in nonlymphoid tissue that provide enhanced local immunity during infection with herpes simplex virus. Nat Immunol. 2009;10(5):524-30. PubMed PMID: 19305395. doi: 10.1038/ni.1718

20. Hofmann M, Pircher H. E-cadherin promotes accumulation of a unique memory CD8 T-cell population in murine salivary glands. Proc Natl Acad Sci U S A. 2011;108(40):16741-6. PubMed PMID: 21930933. Pubmed Central PMCID: 3189029. doi: $10.1073 /$ pnas. 1107200108

21. Jiang X, Clark RA, Liu L, Wagers AJ, Fuhlbrigge RC, Kupper TS. Skin infection generates non-migratory memory CD8+ T(RM) cells providing global skin immunity. Nature. 2012;483(7388):227-31. PubMed PMID: 22388819. Pubmed Central PMCID: 3437663. doi: 10.1038/nature10851

22. Liu L, Zhong Q, Tian T, Dubin K, Athale SK, Kupper TS. Epidermal injury and infection during poxvirus immunization is crucial for the generation of highly protective T cell-mediated immunity. Nat Med. 2010;16(2):224-7. PubMed PMID: 20081864. Pubmed Central PMCID: 3070948. doi: 10.1038/nm.2078

23. Masopust D, Choo D, Vezys V, Wherry EJ, Duraiswamy J, Akondy R, Wang J, Casey KA, Barber DL, Kawamura KS, Fraser KA, Webby RJ, Brinkmann V, Butcher EC, Newell KA, Ahmed R. Dynamic T cell migration program provides resident memory within intestinal epithelium. J Exp Med. 2010;207(3):553-64. PubMed PMID: 20156972. Pubmed Central PMCID: 2839151. doi: 10.1084/jem.20090858

24. Teijaro JR, Turner D, Pham Q, Wherry EJ, Lefrancois L, Farber DL. Cutting edge: Tissue-retentive lung memory CD4 T cells mediate optimal protection to respiratory virus infection. J Immunol. 2011;187(11):5510-4. PubMed PMID: 22058417. Pubmed Central PMCID: 3221837. doi: 10.4049/jimmunol.1102243

25. Wakim LM, Woodward-Davis A, Bevan MJ. Memory T cells persisting within the brain after local infection show functional adaptations to their tissue of residence. Proc Natl Acad Sci U S A. 2010;107(42):17872-9. PubMed PMID: 20923878. Pubmed Central PMCID: 2964240. doi: 10.1073/pnas.1010201107

26. Sathaliyawala T, Kubota M, Yudanin N, Turner D, Camp P, Thome JJ, Bickham KL, Lerner H, Goldstein M, Sykes M, Kato T, Farber DL. Distribution and compartmentalization of human circulating and tissue-resident memory T cell subsets. Immunity. 2013;38(1):187-97. PubMed PMID: 23260195. Pubmed Central PMCID: 3557604. doi: 10.1016/j.immuni.2012.09.020

27. Beura LK, Masopust D. SnapShot: resident memory T cells. Cell. 2014;157(6):14881488.e1. PubMed PMID: 24906159. doi: 10.1016/j.cell.2014.05.026

28. Nakanishi Y, Lu B, Gerard C, Iwasaki A. CD8(+) T lymphocyte mobilization to virus-infected tissue requires CD4(+) T-cell help. Nature. 2009;462(7272):510-3. PubMed PMID: 19898495. Pubmed Central PMCID: 2789415. doi: 10.1038/nature 08511

29. Laidlaw BJ, Zhang N, Marshall HD, Staron MM, Guan T, Hu Y, Cauley LS, Craft J, Kaech SM. CD4+ T cell help guides formation of CD103+ lung-resident memory 
CD8+ T cells during influenza viral infection. Immunity. 2014;41(4):633-45. PubMed PMID: 25308332. Pubmed Central PMCID: PMC4324721. doi: 10.1016/j.immuni.2014.09.007

30. Mackay LK, Wynne-Jones E, Freestone D, Pellicci DG, Mielke LA, Newman DM, Braun A, Masson F, Kallies A, Belz GT, Carbone FR. T-box Transcription Factors Combine with the Cytokines TGF-beta and IL-15 to Control Tissue-Resident Memory T Cell Fate. Immunity. 2015;43(6):1101-11. PubMed PMID: 26682984. doi: 10.1016/j. immuni.2015.11.008

31. Sabbaj S, Hel Z, Richter HE, Mestecky J, Goepfert PA. Menstrual blood as a potential source of endometrial derived CD3+ T cells. PLoS One. 2011;6(12):e28894. PubMed PMID: 22174921. Pubmed Central PMCID: 3235171. doi: 10.1371/journal. pone.0028894

32. Sabbaj S, Heath SL, Bansal A, Vohra S, Kilby JM, Zajac AJ, Goepfert PA. Functionally competent antigen-specific CD127(hi) memory CD8+ T cells are preserved only in HIV-infected individuals receiving early treatment. J Infect Dis. 2007;195(1):108-17. PubMed PMID: 17152014. JID36822 [pii] doi: 10.1086/509510

33. Posavad CM, Zhao L, Mueller DE, Stevens CE, Huang ML, Wald A, Corey L. Persistence of mucosal T-cell responses to herpes simplex virus type 2 in the female genital tract. Mucosal Immunol. 2015;8(1):115-26. PubMed PMID: 24917455. Pubmed Central PMCID: PMC4263695. doi: 10.1038/mi.2014.47

34. Zhu J, Peng T, Johnston C, Phasouk K, Kask AS, Klock A, Jin L, Diem K, Koelle DM, Wald A, Robins H, Corey L. Immune surveillance by CD8alphaalpha+ skin-resident T cells in human herpes virus infection. Nature. 2013;497(7450):494-7. PubMed PMID: 23657257. Pubmed Central PMCID: PMC3663925. doi: 10.1038/nature12110

35. Bergsbaken T, Bevan MJ. Proinflammatory microenvironments within the intestine regulate the differentiation of tissue-resident CD8(+) T cells responding to infection. Nat Immunol. 2015;16(4):406-14. PubMed PMID: 25706747. Pubmed Central PMCID: PMC4368475. doi: 10.1038/ni.3108

36. Iijima N, Iwasaki A. T cell memory. A local macrophage chemokine network sustains protective tissue-resident memory CD4 T cells. Science. 2014;346(6205):93-8. PubMed PMID: 25170048. Pubmed Central PMCID: PMC4254703. doi: 10.1126/science. 1257530

37. Schenkel JM, Fraser KA, Beura LK, Pauken KE, Vezys V, Masopust D. T cell memory. Resident memory CD8 T cells trigger protective innate and adaptive immune responses. Science. 2014;346(6205):98-101. PubMed PMID: 25170049. Pubmed Central PMCID: PMC4449618. doi: 10.1126/science.1254536

38. Sheridan BS, Pham QM, Lee YT, Cauley LS, Puddington L, Lefrancois L. Oral infection drives a distinct population of intestinal resident memory CD8(+) T cells with enhanced protective function. Immunity. 2014;40(5):747-57. PubMed PMID: 24792910. Pubmed Central PMCID: PMC4045016. doi: 10.1016/j.immuni.2014.03.007

39. Clark RA, Watanabe R, Teague JE, Schlapbach C, Tawa MC, Adams N, Dorosario AA, Chaney KS, Cutler CS, Leboeuf NR, Carter JB, Fisher DC, Kupper TS. Skin effector memory $\mathrm{T}$ cells do not recirculate and provide immune protection in alemtu- 
zumab-treated CTCL patients. Sci Transl Med. 2012;4(117):117ra7. PubMed PMID: 22261031. Pubmed Central PMCID: PMC3373186. doi: 10.1126/scitranslmed.3003008

40. Watanabe R, Gehad A, Yang C, Scott LL, Teague JE, Schlapbach C, Elco CP, Huang V, Matos TR, Kupper TS, Clark RA. Human skin is protected by four functionally and phenotypically discrete populations of resident and recirculating memory T cells. Sci Transl Med. 2015;7(279):279ra39. PubMed PMID: 25787765. Pubmed Central PMCID: PMC4425193. doi: 10.1126/scitranslmed.3010302

41. Glennie ND, Yeramilli VA, Beiting DP, Volk SW, Weaver CT, Scott P. Skin-resident memory CD4+ T cells enhance protection against Leishmania major infection. J Exp Med. 2015;212(9):1405-14. PubMed PMID: 26216123. Pubmed Central PMCID: PMC4548053. doi: 10.1084/jem.20142101

42. Gonzalez Y, Herrera MT, Juarez E, Salazar-Lezama MA, Bobadilla K, Torres M. CD161 Expression Defines a Th1/Th17 Polyfunctional Subset of Resident Memory T Lymphocytes in Bronchoalveolar Cells. PLoS One. 2015;10(4):e0123591. PubMed PMID: 25906076. Pubmed Central PMCID: PMC4408072. doi: 10.1371/journal. pone. 0123591

43. Ugur M, Schulz O, Menon MB, Krueger A, Pabst O. Resident CD4+ T cells accumulate in lymphoid organs after prolonged antigen exposure. Nat Commun. 2014;5:4821. PubMed PMID: 25189091. doi: 10.1038/ncomms5821

44. Swaims-Kohlmeier A, Haaland RE, Haddad LB, Sheth AN, Evans-Strickfaden T, Lupo LD, Cordes S, Aguirre AJ, Lupoli KA, Chen CY, Ofotukun I, Hart CE, Kohlmeier JE. Progesterone Levels Associate with a Novel Population of CCR5+CD38+ CD4 T Cells Resident in the Genital Mucosa with Lymphoid Trafficking Potential. J Immunol. 2016;197(1):368-76. PubMed PMID: 27233960. Pubmed Central PMCID: PMC4912879. doi: 10.4049/jimmunol.1502628

45. Elrefaei M, McElroy MD, Preas CP, Hoh R, Deeks S, Martin J, Cao H. Central memory $\mathrm{CD} 4+\mathrm{T}$ cell responses in chronic HIV infection are not restored by antiretroviral therapy. J Immunol. 2004;173(3):2184-9. PubMed PMID: 15265956.

46. Emu B, Moretto WJ, Hoh R, Krone M, Martin JN, Nixon DF, Deeks SG, McCune JM. Composition and function of $\mathrm{T}$ cell subpopulations are slow to change despite effective antiretroviral treatment of HIV disease. PLoS One. 2014;9(1):e85613. PubMed PMID: 24465619. Pubmed Central PMCID: PMC3897457. doi: 10.1371/journal. pone. 0085613

47. Mackay LK, Rahimpour A, Ma JZ, Collins N, Stock AT, Hafon ML, Vega-Ramos J, Lauzurica P, Mueller SN, Stefanovic T, Tscharke DC, Heath WR, Inouye M, Carbone FR, Gebhardt T. The developmental pathway for CD103(+)CD8+ tissue-resident memory T cells of skin. Nat Immunol. 2013;14(12):1294-301. PubMed PMID: 24162776. doi: 10.1038/ni.2744

48. Zhang N, Bevan MJ. Transforming growth factor-beta signaling controls the formation and maintenance of gut-resident memory $\mathrm{T}$ cells by regulating migration and retention. Immunity. 2013;39(4):687-96. PubMed PMID: 24076049. Pubmed Central PMCID: PMC3805703. doi: 10.1016/j.immuni.2013.08.019 
49. Francis SC, Hou Y, Baisley K, van de Wijgert J, Watson-Jones D, Ao TT, Herrera C, Maganja K, Andreasen A, Kapiga S, Coulton GR, Hayes RJ, Shattock RJ. Immune Activation in the Female Genital Tract: Expression Profiles of Soluble Proteins in Women at High Risk for HIV Infection. PLoS One. 2016;11(1):e0143109. PubMed PMID: 26814891. Pubmed Central PMCID: PMC4729472. doi: 10.1371/journal. pone.0143109

50. Chegini N, Zhao Y, Williams RS, Flanders KC. Human uterine tissue throughout the menstrual cycle expresses transforming growth factor-beta 1 (TGF beta 1), TGF beta 2, TGF beta 3, and TGF beta type II receptor messenger ribonucleic acid and protein and contains [125I]TGF beta 1-binding sites. Endocrinology. 1994;135(1):439-49. PubMed PMID: 8013382. doi: 10.1210/endo.135.1.8013382

51. Mueller SN, Mackay LK. Tissue-resident memory T cells: local specialists in immune defence. Nat Rev Immunol. 2016;16(2):79-89. PubMed PMID: 26688350. doi: 10.1038/ nri.2015.3

52. Steinert EM, Schenkel JM, Fraser KA, Beura LK, Manlove LS, Igyarto BZ, Southern PJ, Masopust D. Quantifying Memory CD8 T Cells Reveals Regionalization of Immunosurveillance. Cell. 2015;161(4):737-49. PubMed PMID: 25957682. Pubmed Central PMCID: PMC4426972. doi: 10.1016/j.cell.2015.03.031

53. Shacklett BL, Cox CA, Sandberg JK, Stollman NH, Jacobson MA, Nixon DF. Trafficking of human immunodeficiency virus type 1-specific CD8+ T cells to gut-associated lymphoid tissue during chronic infection. J Virol. 2003;77(10):5621-31. PubMed PMID: 12719554. Pubmed Central PMCID: PMC154016.

54. Sabbaj S, Ghosh MK, Edwards BH, Leeth R, Decker WD, Goepfert PA, Aldrovandi GM. Breast milk-derived antigen-specific CD8+ T cells: an extralymphoid effector memory cell population in humans. J Immunol. 2005;174(5):2951-6. PubMed PMID: 15728507. 174/5/2951 [pii]

\section{COPYRIGHT}

(C) Pathogens and Immunity 2017

This work is licensed under a Creative Commons Attribution 4.0 International License. To view a copy of this license, visit http://creativecommons.org/licenses/by/4.0/ 


\section{SUPPLEMENTAL MATERIALS}

A.

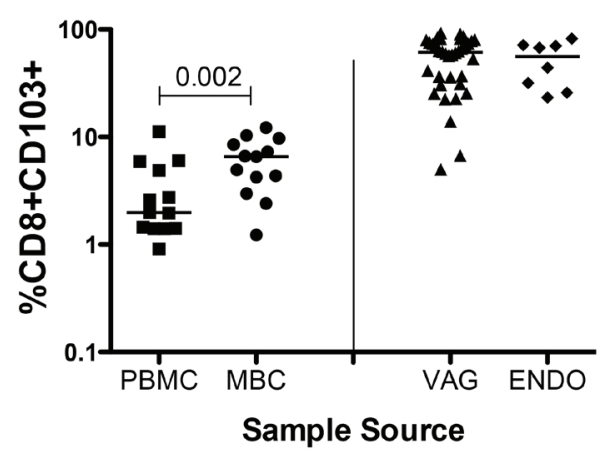

C.

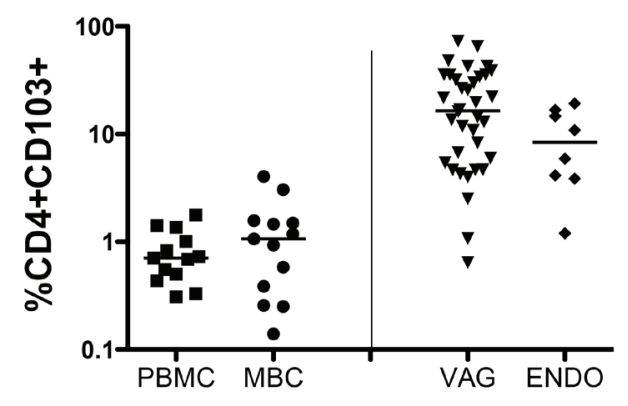

E.

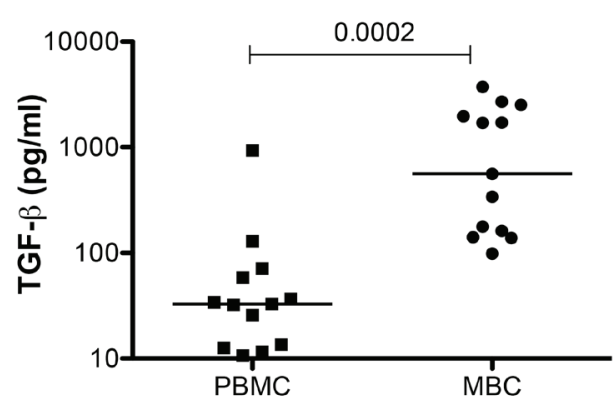

Source of Plasma
B. $\quad \mathrm{HIV}+$

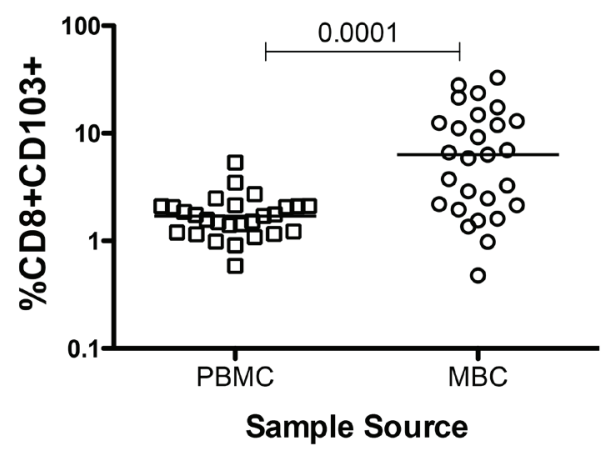

D.

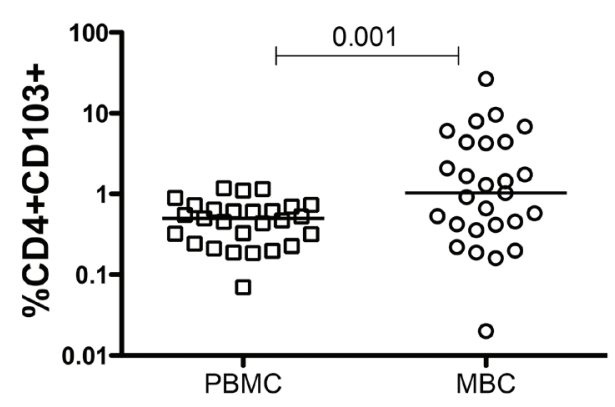

F.

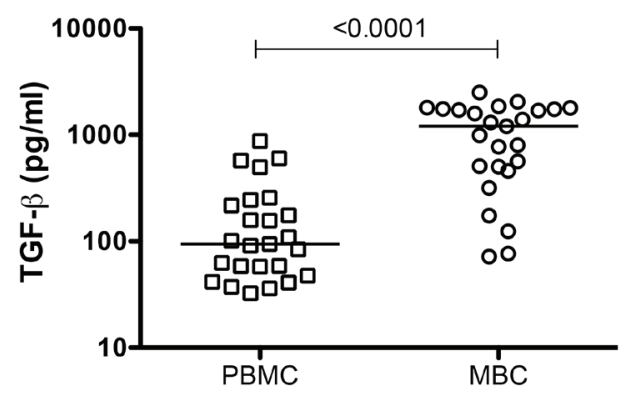

Source of Plasma

Supplemental Figure 1. Percent of CD103 and TGF- $\beta$ concentration from HIV-seronegative samples (closed symbols) and HIV-seropositive samples (open symbols). (A) \%CD8 ${ }^{+} \mathrm{CD} 103^{+}$. (B) $\% \mathrm{CD}^{+} \mathrm{CD} 103^{+}$. (C) $\% \mathrm{CD}^{+} \mathrm{CD} 103^{+}$(D) $\% \mathrm{CD}^{+} \mathrm{CD} 103^{+}$(E) TGF- $\beta$ concentration in plasma from PBMC and MBC from HIV-seronegative samples. (F) TGF- $\beta$ concentration in plasma from PBMC and MBC from HIV-seropositive samples. Horizontal line represents median value. Statistically significant differences $(P<0.05)$ were obtained using the Wilcoxon Rank test for paired samples. Although not noted in the graph, differences were also detected between MBC and tissues (VAG and ENDO). 